\title{
Determinants of bone and blood lead concentrations in the early postpartum period
}

\author{
Mary Jean Brown, Howard Hu, Teresa Gonzales-Cossio, Karen E Peterson, \\ Luz-Helena Sanin, Maria de Luz Kageyama, Eduardo Palazuelos, Antonio Aro, \\ Lourdes Schnaas, Mauricio Hernandez-Avila
}

Department of Maternal and Child

Health, Harvard School of Public Health, Boston, Massachusetts, USA M J Brown

K E Peterson

Centro de

Investigaciones en Salud Poblacional, Instituto Nacional de Salud Pucblica, Cuernavaca, Morelos, Mexico

T Gonzales-Cossio L-H Sanin

M de Luz Kageyama

L Schnaas

M Hernandez-Avila

Department of Nutrition, Harvard School of Public Health, Boston, Massachusetts, USA K E Peterson

A Aro

Universidad Autonoma de Chichuahua, Chihuahua, Mexico L-H Sanin

American British Cowdray Hospital, Mexico City, Mexico

M de Luz Kageyama E Palazuelos

Channing Laboratory, Department of Medicine, Brigham and Women's Hospital, Harvard Medical

School and Occupational Health Program, Department of Environmental Health, Harvard School of Public Health, Boston, Massachusetts, USA $\mathrm{H} \mathrm{Hu}$

A Aro

Correspondence to: Dr H Hu, Channing Laboratory, 181 Longwood Avenue, Boston, MA 02115, USA

Accepted 7 April 2000

\begin{abstract}
Objective-This study investigated determinants of bone and blood lead concentrations in 430 lactating Mexican women during the early postpartum period and the contribution of bone lead to blood lead.
\end{abstract}

Methods-Maternal venous lead was measured at delivery and postpartum, and bone lead concentrations, measured with in vivo $K-x$ ray fluorescence, were measured post partum. Data on environmental exposure, demographic characteristics, and maternal factors related to exposure to lead were collected by questionnaire. Linear regression was used to examine the relations between bone and blood lead, demographics, and environmental exposure variables.

Results-Mean (SD) blood, tibial, and patellar lead concentrations were 9.5 (4.5) $\mu \mathrm{g} / \mathrm{dl}, 10.2$ (10.1) $\mu \mathrm{g} \mathrm{Pb} / \mathrm{g}$ bone mineral, and $15.2(15.1) \mu \mathrm{gb} / \mathrm{g}$ bone mineral respectively. These values are considerably higher than values for women in the United States. Older age, the cumulative use of lead glazed pottery, and higher proportion of life spent in Mexico City were powerful predictors of higher bone lead concentrations. Use of lead glazed ceramics to cook food in the past week and increased patellar lead concentrations were significant predictors of increased blood lead. Patellar lead concentrations explained one third of the variance accounted for by the final blood lead model. Women in the 90th percentile for patella lead had an untransformed predicted mean blood lead concentration $3.6 \mu \mathrm{g} / \mathrm{dl}$ higher than those in the 10 th percentile. Conclusions-This study identified the use of lead glazed ceramics as a major source of cumulative exposure to lead, as reflected by bone lead concentrations, as well as current exposure, reflected by blood lead, in Mexico. A higher proportion of life spent in Mexico City, a proxy for exposure to leaded gasoline emissions, was identified as the other major source of cumulative lead exposure. The influence of bone lead on blood lead coupled with the long half life of lead in bone has implications for other populations and suggests that bone stores may pose a threat to women of reproductive age long after exposure has declined.

(Occup Environ Med 2000;57:535-541)
Keywords: postpartum; blood lead; bone lead

The harmful effects of lead on infant and child development have been well documented. ${ }^{1}$ As well as the risk posed by environmental exposure, concerns have been raised about fetal and neonatal exposure to maternal lead stores that may be released as bone is mobilised to meet the calcium demands of pregnancy and lactation. $^{2}$ Data available from both animal models, and to a lesser extent from humans, indicate a rise in blood lead concentrations during pregnancy coincident with maternal bone demineralisation to meet increased fetal requirements. ${ }^{34}$ In a recent study, the skeletal contribution to blood lead concentration measured by changes in the lead isotope ratio, was estimated as $31 \%$ in seven pregnant women. ${ }^{5}$

Bone is the repository of most lead that is not excreted. In adults the half life of lead in trabecular bone is several years and in cortical bone probably decades. ${ }^{6}{ }^{7}$ Bone is not an inactive reservoir. Recognition of bone as a biological maker of cumulative exposure to lead as well as a potential dynamic source of endogenous lead exposure has resulted in several investigations of the relation between bone lead concentrations and medical conditions associated with lead exposure in adults. There is good evidence that in men and women the risk for hypertension increases as bone lead concentrations increase. ${ }^{89}$ Higher bone lead has been found to be a risk factor for increased reports of delinquency in adolescent males, decreased haemoglobin in construction workers, and poorer performance on cognitive tests in adult men. ${ }^{10-13}$ In several studies, after adjustment for bone lead concentrations, many of the other risk factors associated with adverse health outcomes including age, race, and education level, were no longer significant.

During the last half of pregnancy there is a dramatic increase in fetal need for and maternal provision of calcium. ${ }^{14}$ Skeletal calcium is mobilised to meet fetal and later neonatal demands for calcium. Decreases in bone mineral content and bone mineral density in the range of $3 \%$ in the distal radius and lumbar vertebrae during pregnancy have been reported. ${ }^{15}$

There is no apparent maternal-fetal barrier to lead and fetal and maternal blood lead are nearly equal. ${ }^{16}$ Several prospective studies suggest that in utero exposure to maternal blood lead of $10-20 \mu \mathrm{g} / \mathrm{dl}$ may compromise children's early development. ${ }^{17}$ Recent work also suggests 
an inverse relation between maternal lead burden, estimated by bone lead concentrations, and birth size in offspring for women with relatively low blood lead ${ }^{18}$ (Hernandez Avila, personal communication).

Concentrations of lead in air in Mexico have decreased over the past decade in response to regulatory control of emissions of leaded gasoline. However, some high dose lead sources remain including residual contamination of soil and dust by gasoline exhaust. Also, lead glazed pottery used for cooking and food storage is a major source of exposure. Romieu et al found that $81 \%$ of the lead glazed ceramics sampled in 54 households leached lead in excess of the Mexican norm of $7 \mathrm{ppm}$. In this study the mean (range) quantity of lead leached was 2163.3 (0.05 to 4968 ) ppm. ${ }^{19}$ Thus, women in Mexico have current environmental sources as well as bone lead stores that may contribute to blood lead. The development of $x$ ray fluorescence (XRF) provides a method for in vivo measurement of bone lead concentrations and makes possible exploration of the interrelations between cumulative exposure to lead, as reflected by concentrations of lead in bone measured by XRF, maternal concentrations of blood lead, environmental sources of exposure, and host factors. ${ }^{20}$

\section{Methods}

SAMPLE POPULATION

We reviewed baseline and follow up data from women who were enrolled in a randomised trial to assess the effect of calcium supplements on blood lead during lactation. Between 28 April 1994 and 9 June 1995, venous or cord blood samples were obtained at the time of delivery from 1398 women admitted to one of three hospitals in Mexico City serving women with low to moderate incomes. Of the women who had both cord and venous blood lead measured during delivery $(n=1167)$, a total of 516 returned for a follow up appointment at the study site. It was estimated that a study of this size had the power to detect a $30 \%-50 \%$ decrease in blood lead. Failure to return for follow up was related to living outside the study area or the decision to bottle feed the infant. The research protocol was approved by the Human Subjects Committee of the National Institute of Public Health of Mexico and the Harvard School of Public Health.

BLOOD LEAD MEASUREMENT

Blood samples were collected in lead free tubes and analysed by the staff of the trace metals laboratory of the American British Cowdray Hospital in Mexico City with graphite furnace atomic absorption spectrophotometry (Perkin Elmer 3000). The laboratory participates in the comparative proficiency testing programme of the Wisconsin State Laboratory of the Bureau of Maternal and Child Health, Health Resources and Services Administration, US Public Health Service. On tests of blinded specimens in the range of $0-8,14-22$ and $40-50 \mathrm{mg} / \mathrm{dl}$, the laboratory performed with an accuracy within $5.0 \%$ and a coefficient of variation of $<15 \%$.
BONE LEAD MEASUREMENTS

For the present study, 30 minute bone lead measurements were taken from each subject's left mid-tibial shaft (cortical bone) and left patella (trabecular bone) after each region had been washed with a $50 \%$ solution of isopropyl alcohol. The K-x ray beam collimator was placed perpendicular to the bone surface of the tibia and at $30^{\circ}$ in the lateral direction of the patella. Repeated measurements in 35 subjects showed an intraclass correlation of 0.84 and 0.82 for tibia and patella, respectively. ${ }^{21}$ The physical principles, technical specifications, and validation of this instrument have already been described. ${ }^{202-24}$

\section{QUESTIONNAIRE}

Participants were interviewed at the research office by trained personnel who used a questionnaire to assess social and demographic characteristics, reproductive history, maternal health, and known risk factors for increased blood lead documented in previous studies. ${ }^{25} 26$ The questionnaire includes items about exposure to lead-such as the use of low temperature fired lead glazed pottery to store or prepare food recently and in the past, smoking history, proximity to traffic or other point sources of lead, and occupational history. Participants were also given photographs of the typically red pottery to help identify it.

\section{NUTRITIONAL STATE}

Packed cell volume and haemoglobin concentrations were measured during the postpartum visit. Women also completed a 116 item food frequency questionnaire (FFQ). The validity and reproducibility of this tool to assess nutrient intake in Mexican women has been shown in a study comparing the questionnaire with four 4 day or 24 hour recalls scheduled 3 months apart over 1 year. ${ }^{27}$ The FFQ uses an international source complemented with published food composition tables specific for the Mexican diet. The correlation between the FFQ used in this study and the 24 hour recalls for calcium in the validation study ranged from 0.38 to 0.52 , indicating reasonable estimates of current calcium intake. ${ }^{28}$

\section{STATISTICAL ANALYSIS}

We examined the relation between concentrations of lead in blood and bone, known sources of environmental exposure, and confounding factors. For this study, data analysis was restricted to those women with measured concentrations of cord and postpartum blood lead and patellar and tibial lead, who delivered a single infant and who were exclusively breast feeding at the time of the first visit. We excluded the one woman who was over 40 years old. We also excluded women with incomplete information and those with high bone lead uncertainty values due to movement out of the measurement field or extreme thickness of overlying tissue as indicated by patellar measurement uncertainty of $>15 \mu \mathrm{g} \mathrm{Pb} / \mathrm{g}$ bone mineral or tibial uncertainty measurement of $>10 \mu \mathrm{g} \mathrm{Pb} / \mathrm{g}$ bone mineral. These restrictions limited the study population to 430 women. 
Bivariate analyses were conducted on all variables and linear regression models were constructed to examine the relation between independent variables and concentrations of bone and blood lead. Saturated models were constructed for each biomarker with variables significant at the univariate level of $\mathrm{p} \leqslant 0.10$. Final models were developed with a stepwise regression procedure which permitted reexamination, at every step, of the variables incorporated into the model in previous steps allowing only those categorical variables with grouped $\mathrm{p}$ values $\leqslant 0.05$ to stay in the model. ${ }^{29}$ For blood lead, the saturated model and the selected model excluding and including patel- lar lead were compared to find the explanatory power of patellar lead for blood lead.

Models which included bone lead as a dependent variable, incorporated weights based on the inverse of the square of the individual estimates of bone lead uncertainty. These uncertainty values are, in effect, estimates of the SD of multiple measurements at the site and their use minimises the effect of misclassification due to measurement error. ${ }^{30}$ The actual measurements in conjunction with individual estimates of uncertainty are then used to modify the standard regression model with bone lead as an explanatory variable.

Table 1 Mean (SD) concentrations of lead in bone and blood in women early after giving birth by participant characteristic

\begin{tabular}{|c|c|c|c|}
\hline & Blood Pbt $(\mu g / d l)$ & $\begin{array}{l}\text { Tibial Pbf } \\
\text { ( } \mu \mathrm{g} \mathrm{Pb/g} \text { bone mineral) }\end{array}$ & $\begin{array}{l}\text { Patellar Pb } \neq \\
\text { ( } \mu \mathrm{g} \mathrm{Pb/g} \text { bone mineral) }\end{array}$ \\
\hline \multicolumn{4}{|l|}{ Demographic characteristics: } \\
\hline \multicolumn{4}{|l|}{ Age: } \\
\hline$<20(n=83)$ & $9.5(4.6)$ & $7.9(8.2)^{\star \star}$ & $10.6(13.1)^{\star \star}$ \\
\hline $20-24(n=150)$ & $9.5(5.9)$ & $8.7(9.5)$ & $14.1(15.2)$ \\
\hline $25-30(n=140)$ & $9.4(4.0)$ & $11.8(11.5)$ & $18.0(15.73)$ \\
\hline $31-40(\mathrm{n}=57)$ & $9.7(4.5)$ & $13.8(9.4)$ & $17.7(14.2)$ \\
\hline \multicolumn{4}{|l|}{ Mother's education (y): } \\
\hline $0-6(n=102)$ & $9.6(4.6)$ & $9.4(9.7)$ & $14.4(14.4)$ \\
\hline $7-9(\mathrm{n}=159)$ & $9.2(4.2)$ & $10.7(11.3)$ & $16.1(16.1)$ \\
\hline$>9(n=169)$ & $9.7(5.7)$ & $10.2(9.2)$ & $14.7(14.4)$ \\
\hline \multicolumn{4}{|l|}{ Occupant density : } \\
\hline $1(\mathrm{n}=90)$ & $9.7(6.6)$ & $10.9(9.0)$ & $15.1(12.6)$ \\
\hline $2(n=259)$ & $9.5(4.4)$ & $10.3(10.9)$ & $14.6(16.3)$ \\
\hline $3(\mathrm{n}=58)$ & $9.0(3.9)$ & $8.7(8.2)$ & $17.4(12.9)$ \\
\hline $4(n=23)$ & $9.5(4.7)$ & $10.9(9.8)$ & $16.5(14.5)$ \\
\hline \multicolumn{4}{|l|}{ Reproductive history: } \\
\hline \multicolumn{4}{|l|}{ Pregnancies (n)甲: } \\
\hline $1(n=176)$ & $9.7(5.7)$ & $9.0(8.4)^{\star \star}+\dagger$ & $13.2(13.0)^{\star \star}+\dagger$ \\
\hline$\geqslant 2(\mathrm{n}=254)$ & $9.5(4.3)$ & $11.1(11.2)$ & $16.5(16.2)$ \\
\hline \multicolumn{4}{|l|}{ Lifetime-months breast feeding: } \\
\hline$\leqslant 6(n=288)$ & $9.6(5.1)$ & $9.7(9.6)$ & $14.2(14.0)^{\star \star}+\dagger$ \\
\hline$>6(\mathrm{n}=142)$ & $9.3(4.5)$ & $11.2(11.1)$ & $17.2(17.0)$ \\
\hline \multicolumn{4}{|l|}{ Age at menarche $(y)$ : } \\
\hline$\leqslant 12(\mathrm{n}=174)$ & $9.5(5.5)$ & $10.3(10.3)$ & $15.1(15.3)$ \\
\hline$>12(\mathrm{n}=247)$ & $9.5(4.5)$ & $10.0(10.1)$ & $15.2(14.8)$ \\
\hline Unknown & $8.2(2.8)$ & $10.2(10.1)$ & $15.2(15.1)$ \\
\hline \multicolumn{4}{|l|}{ Exposure to lead: } \\
\hline \multicolumn{4}{|l|}{ Use of lead glazed pottery } \\
\hline Never $(n=51)$ & $7.5(3.1)$ & $5.9(9.3)$ & $12.7(13.9)$ \\
\hline Current not past $(n=43)$ & $10.6(5.4)$ & $8.4(7.8)$ & $17.8(10.6)$ \\
\hline Past not current $(\mathrm{n}=167)$ & $9.3(5.6)$ & $10.1(8.9)$ & $13.0(15.2)$ \\
\hline Always $(\mathrm{n}=169)$ & $10.0(4.2)^{\star \star}$ & $12.1(11.5)^{\star \star}$ & $17.4(15.9)^{\star \star}$ \\
\hline \multicolumn{4}{|c|}{ Use of lead glazed pottery to store food in the past week: } \\
\hline No $(n=354)$ & $9.4(5.1)^{\star \star}$ & $9.8(10.0)^{\star}$ & $15.1(14.8)$ \\
\hline Yes $(n=76)$ & $10.1(3.7)$ & $12.2(10.6)$ & $15.5(16.4)$ \\
\hline \multicolumn{4}{|c|}{ Use of lead glazed pottery to cook food in the past week: } \\
\hline No $(n=276)$ & $8.6(3.7)^{\star \star}$ & $9.0(8.8)^{\star \star}$ & $13.4(14.5)^{\star \star}$ \\
\hline Yes $(n=154)$ & $11.1(6.3)$ & $12.3(12.0)$ & $18.4(15.5)$ \\
\hline \multicolumn{4}{|l|}{ Life spent in Mexico City (\%): } \\
\hline$<40(\mathrm{n}=79)$ & $8.8(4.8)^{\star}$ & $6.7(9.2)^{\star \star}$ & $11.0(13.9)^{\star \star}$ \\
\hline$>40(\mathrm{n}=351)$ & $9.6(4.9)$ & $10.9(10.1)$ & $16.0(15.0)$ \\
\hline \multicolumn{4}{|l|}{ Type of water in house: } \\
\hline Outside public tap $(n=173)$ & $9.6(4.6)$ & $9.0(9.4)^{\star}$ & $14.1(13.3)$ \\
\hline Inside running water $(n=160)$ & $9.2(5.6)$ & $11.0(10.6)$ & $17.0(16.9)$ \\
\hline Other $(\mathrm{n}=97)$ & $9.8(4.2)$ & $11.2(10.5)$ & $14.1(14.7)$ \\
\hline \multicolumn{4}{|l|}{ Smoking: } \\
\hline Ever smoked $(n=178)$ & $9.6(5.6)$ & $11.6(10.8)^{\star \star}$ & $17.0(16.1)^{\star \star}$ \\
\hline Never smoked $(n=252)$ & $9.4(4.4)$ & $9.2(9.6)$ & $13.9(14.1)$ \\
\hline \multicolumn{4}{|l|}{ Nutritional state: } \\
\hline \multicolumn{4}{|l|}{ Calcium intake quartile (g/day): } \\
\hline$<830(\mathrm{n}=111)$ & $9.4(4.7)^{\star}$ & $10.4(8.0)$ & $14.5(14.5)$ \\
\hline $830-1007(n=117)$ & $10.1(4.2)$ & $10.5(11.7)$ & $14.7(14.2)$ \\
\hline $1008-1383(n=109)$ & $9.4(4.2)$ & $10.2(9.5)$ & $15.6(14.5)$ \\
\hline$>1383(\mathrm{n}=93)$ & $9.0(6.5)$ & $9.7(11.2)$ & $16.1(17.4)$ \\
\hline Packed cell volume $(\%)$ : & & & \\
\hline$<35(\mathrm{n}=34)$ & $9.0(2.5)$ & $9.1(9.0)$ & $11.1(14.3)$ \\
\hline$\geqslant 35(\mathrm{n}=389)$ & $9.5(5.1)$ & $10.3(10.3)$ & $15.3(15.0)$ \\
\hline Haemoglobin $(\mathrm{g} / \mathrm{dl})$ & & & \\
\hline$<11(\mathrm{n}=29)$ & $9.0(2.7)$ & $8.7(8.6)$ & $12.3(15.2)$ \\
\hline$\geqslant 11(\mathrm{n}=394)$ & $9.5(5.1)$ & $10.3(10.3)$ & $15.3(15.0)$ \\
\hline
\end{tabular}

${ }^{\star} \mathrm{p}<0.10 ;{ }^{\star \star} \mathrm{p}<0.05$

†Differences between categories tested by ANOVA after taking the natural logarithm of blood lead. $\ddagger$ Differences between categories tested by ANOVA.

$\$ N$ umber of occupants per bedroom in house.

IIncludes this pregnancy.

t+When adjusted for age, $\mathrm{p}>0.05$. 
The relations between continuous dependent and independent variables including age, bone lead concentrations, and the log of blood lead concentrations were examined with generalised additive models and local (lowess) smoothing plots. ${ }^{31}$ A linear relation was found between concentrations of tibial and patellar lead (tibia $=10.1+0.5$ (patella); $r=0.11$ ) and $\log$ blood lead as well as between age and tibial lead concentrations (age in years $=-0.2+0.4$ (tibia); $r=0.05)$. The relation between log blood lead and age was a second order polynomial; however, transformation of the blood lead concentration did not improve the model.

\section{Results}

Subjects who participated in the study $(n=430)$ did not differ from those who were not enrolled by age, level of education, marital status, birth outcome, parity, or quartile of calcium intake. Of the 1398 women with either venous or cord blood lead concentrations at delivery, nonparticipants $(n=968)$ were somewhat more likely than participants to report current use of lead glazed pottery. The distribution of blood lead for non-participants was similar to that of enrolled women with $25 \%$ and $29 \%$ of women, respectively, having blood lead $\geqslant 10 \mu \mathrm{g} / \mathrm{dl}$. For participants, the mean (SD) and median blood lead concentrations were $9.5 \mu \mathrm{g} / \mathrm{dl}(4.5)$ and $8.5 \mu \mathrm{g} / \mathrm{dl}$ respectively. The mean (SD) tibial lead concentration was $10.2 \mu \mathrm{g} \mathrm{Pb} / \mathrm{g}$ bone mineral (10.1) with a median value of $9.8 \mu \mathrm{g} \mathrm{Pb} / \mathrm{g}$ bone mineral. For patellar bone lead, the mean (SD) was $15.2 \mu \mathrm{g} \mathrm{Pb} / \mathrm{g}$ bone mineral (15.1) and the median was $14.6 \mu \mathrm{g} \mathrm{Pb} / \mathrm{g}$ bone mineral.

\section{NUTRITIONAL STATE}

Women whose daily calcium intake was in the second quartile, but still substantially below the USDA minimum daily requirement of $1200 \mathrm{~g} /$ day, had higher blood lead than the other participants (table 1). There was no relation between calcium intake and concentrations of either tibial or patellar lead. There was also no relation between mean blood, patellar, or tibial lead and iron status in women with low functional iron (packed cell volume $<35 \%$ or haemoglobin $<11 \mathrm{~g} / \mathrm{dl}$ ). Women who currently used an outside public tap for drinking water had concentrations of tibial lead significantly lower than women whose drinking water came from a tap inside the house or from various other sources including private wells and bottled water (table 1 ).

\section{EXPOSURE TO LEAD}

Women who had ever smoked had higher tibial and patellar lead but not blood lead, than those who had never smoked. There were too few current smokers $(n=17)$ to allow comparison of active smokers with those who had stopped.

The use of lead glazed pottery to cook was a powerful predictor of tibial, patellar and blood lead. Also, the relation between pottery variables and tibial, patellar, or blood lead followed a biologically plausible pattern considering the half life of lead in these various tissues. Tibia lead, with an estimated half life of 20 years or more, was highest for women who reported
Table 2 Final linear regression model for tibial lead concentrations in women early after giving birth $(n=430)$

\begin{tabular}{|c|c|}
\hline Variable & $\begin{array}{l}\text { Tibial } \mathrm{Pb}(\mu \mathrm{g} / \mathrm{g}) \text { estimate } \\
(95 \% \mathrm{CI})\end{array}$ \\
\hline Intercept & $-0.6(-2.5$ to 1.3$)$ \\
\hline Life spent in Mexico City (\%): & \\
\hline$\geqslant 40$ & $5.0(3.8$ to 6.1$)$ \\
\hline Age $(y): \dagger$ & \\
\hline $20-25$ & $1.3(-0.01$ to 2.6$)$ \\
\hline $26-30$ & $4.4(3.1$ to 5.7$)$ \\
\hline $31-40$ & $5.7(4.1$ to 7.3$)$ \\
\hline Use of lead glazed pottery: $\ddagger$ & \\
\hline Now but not in the past & $2.6(0.6$ to 4.6$)$ \\
\hline In the past but not now & $3.3(1.8$ \\
\hline Always & $6.1(4.5$ to 7.7$)$ \\
\hline Total model $\mathrm{R}^{2}$ & 0.12 \\
\hline
\end{tabular}

${ }^{\star}$ Compared with $<40 \%$ of lifetime spent living outside Mexico City.

+Compared with those participants $<20$ years old.

$\ddagger$ Compared with participants who have never used lead glazed pottery to cook or store food.

Table 3 Final linear regression model for concentrations of patellar lead in women early after giving birth $(n=430)$

\begin{tabular}{|c|c|}
\hline Variable & $\begin{array}{l}\text { Patellar } \mathrm{Pb}(\mu \mathrm{g} / \mathrm{g}) \\
\text { estimate }(95 \% \mathrm{CI})\end{array}$ \\
\hline Intercept & $5.3(3.2$ to 7.4$)$ \\
\hline \multicolumn{2}{|l|}{ Life spent in Mexico City $(\%):^{\star}$} \\
\hline$\geqslant 40$ & $5.0(3.3$ to 6.8$)$ \\
\hline \multicolumn{2}{|l|}{ Age $(y): \dagger$} \\
\hline $20-25$ & $3.1(1.2$ to 5.0$)$ \\
\hline $26-30$ & 6.7 ( 4.8 to 8.6$)$ \\
\hline $31-40$ & $4.8(2.4$ to 7.1$)$ \\
\hline \multicolumn{2}{|c|}{ Use of lead glazed pottery in past week: $\ddagger$} \\
\hline To cook food & $5.8(4.3$ to 7.3$)$ \\
\hline To store food & $-3.7(-5.6$ to -1.8$)$ \\
\hline Total model $\mathrm{R}^{2}$ & 0.08 \\
\hline
\end{tabular}

${ }^{\star}$ Compared with $<40 \%$ of lifetime spent living outside Mexico City.

+Compared with those participants $<20$ years old.

$\ddagger$ Compared with participants who have never used lead glazed pottery to cook or store food.

having used lead glazed pottery as children and lower among those with current but not past use. ${ }^{7}$ In less dense patellar bone, with a shorter half life, women with current but not past use had higher patellar lead concentrations. Finally, in blood, with a half life for lead of about 3 weeks, lead concentrations were on average $2.5 \mu \mathrm{g} / \mathrm{dl}$ higher in women who used lead glazed pottery to cook food in the past week compared with those who had not used the pottery (table 1$){ }^{6}$

Age and time spent living in Mexico City were also strongly predictive of both tibial and patellar lead concentrations. To better

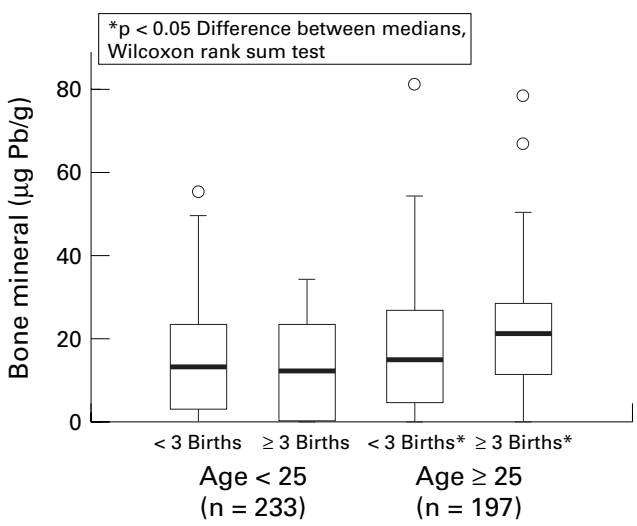

Figure 1 Distribution of patellar lead concentrations by age and parity in 430 Mexican women during the early postpartum period. 
Table 4 Multivariate linear regression models of blood lead concentration in women early after giving birth $(n=430)$

\begin{tabular}{|c|c|c|c|}
\hline \multirow[b]{2}{*}{ Variable } & \multicolumn{3}{|c|}{ Log blood Pb concentration $(\mu g / d l)$} \\
\hline & $\begin{array}{l}\text { Model } 1 \text { Saturated regression } \\
\text { model }{ }^{\star} \text { estimate }(95 \% \mathrm{CI})\end{array}$ & $\begin{array}{l}\text { Model } 2 \text { Selected model without } \\
\text { patellar Pb concentration } \\
\text { estimate }(95 \% \mathrm{CI})\end{array}$ & $\begin{array}{l}\text { Model } 3 \text { Selected model with } \\
\text { patellar Pb concentration } \\
\text { estimate }(95 \% \mathrm{CI})\end{array}$ \\
\hline Intercept & $2.0(1.9$ to 2.10$)$ & $2.0(2.0$ to 2.1$)$ & $2.0 \quad(1.9$ to 2.0$)$ \\
\hline \multicolumn{4}{|l|}{ Calcium intake quartile (g/day): } \\
\hline $830-1007(\mathrm{n}=117)$ & $0.11(0.06$ to 0.17$)$ & $0.1 \quad(-0.06$ to 0.17$)$ & $0.11 \quad(0.06$ to 0.16$)$ \\
\hline $1008-1383(n=109)$ & $0.04(-0.01$ to 0.10$)$ & $0.04(-0.01$ to 0.10$)$ & $0.03 \quad(-0.03$ to 0.08$)$ \\
\hline$>1383(\mathrm{n}=93)$ & $-0.03(-0.09$ to 0.03$)$ & $-0.03(-0.03$ to 0.09$)$ & $-0.05 \quad(-0.10$ to 0.06$)$ \\
\hline \multicolumn{4}{|l|}{ Use of lead glazed pottery: } \\
\hline To store food in past week & $-0.03(-0.19$ to 0.03$)$ & $-0.04(-0.02$ to 0.10$)$ & $-0.011(-0.07$ to 0.05$)$ \\
\hline To cook food in past week & $0.23(0.17$ to 0.28$)$ & $0.23(0.18$ to 0.28$)$ & $0.2 \quad(0.13$ to 0.23$)$ \\
\hline $\begin{array}{l}\text { Life spent in Mexico City (\%): } § \\
\quad \geqslant 40 \%\end{array}$ & $0.10(0.05$ to 0.15$)$ & & \\
\hline Concentration of patellar $\mathrm{Pb}$ & & & $0.007(0.006$ to 0.008$)$ \\
\hline Total model $\mathrm{R}^{2}$ & 0.08 & 0.07 & 0.14 \\
\hline
\end{tabular}

*This model contained all variables related to concentration of blood $\mathrm{Pb}$ at the univariate level with $\mathrm{p} \leqslant 0.10$. †Compared with those in the lowest quartile of calcium intake.

¥Compared with participants who have not used lead glazed pottery in past week.

SCompared with $<40 \%$ of lifetime spent living outside Mexico City.

differentiate between the influence of living in an area of high ambient contamination and that of age, we created a variable of the proportion of a woman's life lived outside the City. This variable was not correlated with age (Pearson's $r^{2}=-0.001$ ). In the final models of both tibial and patellar lead concentrations, the percentage of life lived in Mexico City was strongly related to lead even after controlling for age. Women who had lived outside the City for $40 \%$ or more of their lives, had tibial and patellar bone lead concentrations on average 5 $\mu \mathrm{g} \mathrm{Pb} / \mathrm{g}$ bone mineral lower than those who had lived in Mexico City for a greater proportion of their lives (tables 2 and 3 ).

\section{AGE AND REPRODUCTIVE HISTORY}

In bivariate analysis parity had a positive relation with tibial and patellar lead concentrations. For the patella but not the tibia, lifetimemonths breastfeeding was also significantly related to lead concentration. However, once age was entered into the model, none of these relations remained significant (table 1). Among women 25 years old and older, those with three or more children had significantly higher patellar lead concentrations than those with lower parity. For women less than 25, patellar lead concentrations were lower in the group with three or more children compared with young women with fewer children (mean $9.7 \mu \mathrm{g}$ $\mathrm{Pb} /$ bone mineral $v 13.4 \mu \mathrm{g} \mathrm{Pb} /$ bone mineral) although this difference was not significant (fig

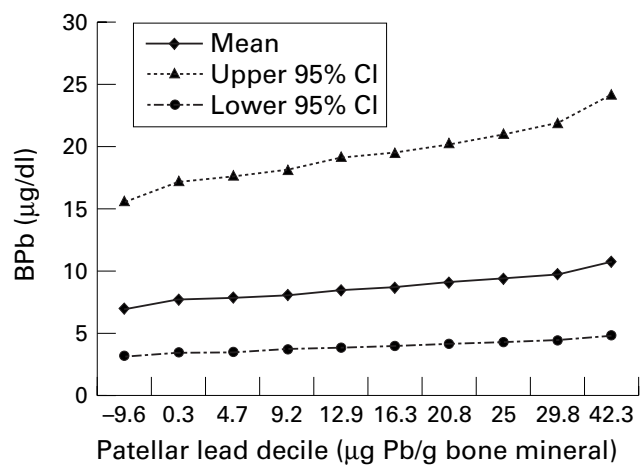

Figure 2 Predicted mean blood lead for 430 Mexican women during the early postpartum period by patellar lead decile.
1). We found a similar relation between patella lead concentrations, age group and lifetime breast feeding experience. Among women over 25 years of age, patellar lead concentrations were significantly higher among women who had breastfed an infant for 6 or more months in their lives but this relation did not hold for younger women (data not shown). There was no interaction between reproductive history, age, and tibial lead concentrations.

In crude analysis, women with patellar lead concentrations in the 90th percentile had a blood lead concentration $3 \mu \mathrm{g} / \mathrm{dl}$ higher than women whose patellar lead concentrations were in the 10th percentile. In the final model of blood lead, patella lead concentrations explained a third of the variance accounted for in the model (table 4). The untransformed predicted mean blood lead of women in the highest patellar lead decile was $10.6 \mu \mathrm{g} / \mathrm{dl}$ whereas for women in the lowest it was $7 \mu \mathrm{g} / \mathrm{dl}$ (fig 2).

\section{Discussion}

Blood lead concentrations in Mexico City have declined dramatically in the past 20 years, undoubtedly as a result of reduced leaded gasoline emissions. Although population based screening has not been conducted, investigators have tested many residents over the past 30 years. Studies conducted during the 1970s reported mean umbilical cord blood concentrations of $13.6 \mu \mathrm{g} / \mathrm{dl} .{ }^{32} \mathrm{~A}$ World Health Organisation study of schoolteachers in 1981 found a mean lead concentration of $26.9 \mu \mathrm{g} / \mathrm{dl} .^{33}$ Ten years later, among a randomly selected sample of low income women aged 21-57 years, the mean concentration was $9.6 \mu \mathrm{g} / \mathrm{dl}$ and $5 \%$ of the women had concentrations $\geqslant 25 \mu \mathrm{g} / \mathrm{dl}$. $^{25}$ Blood lead concentrations in the slightly younger participants of the study reported here are comparable with the mean blood lead concentrations of $9.2 \mu \mathrm{g} / \mathrm{dl}$ found in nonoccupationally exposed adults and children in Ecuador but higher than those in many industrialised nations. ${ }^{34}$ For example, in a randomly selected population of Belgium women, the mean blood lead reported in 1995 was 7.5 $\mu \mathrm{g} / \mathrm{dl}$ and in 1998, a mean blood lead concentration of $5 \mu \mathrm{g} / \mathrm{dl}$ was found in 254 
non-occupationally exposed adults in Barcelona. ${ }^{35}{ }^{36}$ Although the decrease in mean blood lead found in Mexico between 1970 and 1995 indicates how rapidly concentrations in a population can respond to vigorous efforts to reduce exposure, it is noteworthy that the concentrations of lead in bone that we measured in these subjects were about two to three times higher than those found in the 1990s among non-occupationally exposed women of the same age in the United States and Canada. ${ }^{37-39}$

Our finding that for older women patellar lead concentrations increase with increased lifetime number of months breast feeding and parity may seem to contradict previous work. ${ }^{38}{ }^{40}$ However, the previous studies were conducted in the United States during a time when concentrations of lead in air were decreasing. In our study, the increase in patellar lead may reflect bone remodelling activity in the past when ambient lead contamination was high. According to this conceptual model, old bone in such circumstances is replaced with new bone that is richer in lead, thereby increasing or maintaining overall bone lead concentration. ${ }^{41}$ Data on the timing of previous births are unavailable for participants in our study, but the finding that patellar lead concentrations in younger women do not increase with parity or duration of breastfeeding also supports this hypothesis. Also, no interaction was found between these variables and tibia lead concentration which, given the long half life of lead in cortical bone and the ages of the women studied, provides additional support for this interpretation.

Although the relation between patellar lead concentrations and the variables describing use of pottery and living in Mexico City were significant, the model does not explain most of the variation in patellar lead. This suggests that there were other important sources of exposure for these women in the recent past. We did not ask questions about exposure to industrial emissions and were unable to measure recent exposure to gasoline emissions. As patellar lead concentrations contribute to maternal blood lead during the postpartum period, further research in this area is needed.

Previous studies among adults who were not pregnant or lactating suggest that trabecular bone lead makes a significant contribution to blood lead, and that blood lead is higher in women with higher patellar lead concentrations. Hu et al found that a rise in patellar lead of $43 \mu \mathrm{g} / \mathrm{g}$ was associated with a $4.3 \mu \mathrm{g} / \mathrm{dl}$ rise in blood lead among exposed men in the community. ${ }^{42}$ By comparison, in this study of women in the early postpartum period, we found that a rise in patellar lead of $35 \mu \mathrm{g} / \mathrm{g}$ was associated with a rise of $3.6 \mu \mathrm{g} / \mathrm{dl}$ in blood lead.

Because Mexican law prohibits the use of $x$ rays during pregnancy, we were unable to measure women's bone lead during pregnancy. However, the half life of lead in bone and the 0.62 correlation between maternal blood lead in the early postpartum period and cord blood lead (table 4) suggests that the contribution of bone to circulating lead during pregnancy is similar to that during the early postpartum period.

The finding in this study that daily calcium intake is not associated with either patellar or tibial lead concentrations and that blood lead concentrations for women in the lowest intake quartile are the same as those in the highest quartile may illustrate the difficulty of measuring lifetime nutrient intake. The inverse relation between calcium consumption and blood lead is well documented in both animal and other human populations. An earlier pilot study in Mexico found a significant relation between milk and cheese consumption and bone and blood lead. ${ }^{43}$ Although iron has been shown to be an important factor in lead absorption, we did not find a significant relation between haemoglobin or packed cell volume and concentrations of lead in bone or blood. These findings are most likely the result of both the few women with low functional iron and the difficulty of measuring iron deficient anaemia in a population undergoing the physiological changes associated with the early postpartum period. The relation between type of drinking water and blood lead in bivariate analysis may be related to the use of lead in the distribution system for indoor taps and private wells or it may be a reflection of economic status. Once other variables are included in the models, water supply is no longer significantly related to concentration of lead.

This study provides further evidence that current use of lead glazed pottery is significantly related to blood lead and that its use in the past has contributed to women's body burdens. ${ }^{192526394445}$ Efforts to reduce the use of the pottery need to be redoubled and should include a public education campaign, which identifies the hazard of use during pregnancy and informs parents that childhood exposure may have effects later in life. Also, it seems that lead from past maternal exposure is released into the blood during pregnancy and the early postpartum period and contributes to the exposure of the fetus and neonate.

In this study, we cannot assess the concern that the transfer of lead from mother to child, begun during pregnancy, will continue during lactation. The relation between maternal concentrations of lead in blood and breast milk and infant blood lead is an area in which further study is critically needed.

Support for this study came from the US NIEHS P42-ES05947 Project 3, NIEHS Center Grant 2 P30 ES 00002, from NIEHS RO1 ES07821-01A2, and from Consejo Nacional de Ciencia y Tecnologi'a (CONACyT) Grant $4150 \mathrm{M} 9405$, from CONSERVA, Department of Federal District, Mexico. We acknowledge the research assistance of Drs Gale Fleischaker, Jesus Lorenzo, Gustavo Olais, and Francisco Cabral from the Instituto Nacional de Perinatologia, Dolores Saaverdra and the late Carlos Ricalde, both from the Manuel GEA Gonzalez Hosparlos Ricalde, both from the Manuel GEA Gonzalez Hospital, and also the late Rodolofo Munoz from the Hospital de Ginecologia y Obstetricia No 4 Luis Castelazo Ayala, Mexican Social Security Institute. Soma Datta, MBA provided valuable ssistance with computer programming. We also thank the paricipants for their support, which was essential to the project.

1 Boivin MJ, Giordani B. A risk evaluation of the neuropsychological effects of childhood lead toxicity. Developmental Neuropsychology 1995;11:157-80.

2 Silbergeld E. Lead in bone: implications for toxicology during pregnancy and lactation. Environ Health Perspect 1991;
ing 91:63-70. 
3 Rothenberg SJ, Karchmern S, Schnaas L, et al. Changes in serial blood lead levels during pregnancy. Environ Health Perspect 1994;102:876-80.

4 Hallen IP, Jonsson S, Karlsson MO, A Oskarsson. Toxicokinetics of lead in lactating and nonlactating mice. Toxicol Applied Pharmacol 1996;136:342-7.

5 Gulson BI, Jameson CW, Mahaffey KR, et al. Pregnancy increases mobilization of lead from maternal skeleton. $\mathcal{F}$ Lab Clin Med 1997;130::51-62.

6 Rabinowitz MB, Wetherill GW, Kopple JD. Kinetic analysis of lead metabolism in healthy humans. $\mathcal{f}$ Clin Invest 1976;58:260-70.

7 Agency for Toxic Substances and Disease Registry. The nature and extent of lead poisoning in the United States: a report to congress. Atlanta: Department of Health and Human Services, 1988 .

$8 \mathrm{Hu} \mathrm{H}$, Watanabe $\mathrm{H}$, Payton $\mathrm{M}$, et al. The relationship of bone and blood lead to hypertension. $\mathcal{F} A M A 1994 ; 275$ : 1171-6.

9 Korrick S, Hunter D, Rotnitzky A, et al. Lead and hypertension in a sample of middle-aged women. $A m \mathcal{F}$ hypertension in a sample of
Public Health 1999;89:330-5.

10 Needleman HL, Riess JA, Tobin MJ, et al. Bone lead levels and delinquent behavior. $\mathcal{F A M A}$ 1996;275:363-9.

$11 \mathrm{Hu} \mathrm{H}$, Watanabe $\mathrm{H}$, Payton $M$, et al. The relationship between bone lead and hemoglobin. $f A M A$ 1994;272: 1512-17

12 Bleecker ML, Lindgren KN, Ford DP. Differential contribution of current and cumulative indices of lead dose to neuropsychological performance by age. Neurology 1997; 48:639-45.

13 Payton M, Riggs KM, Spiro A, et al. Relations of bone and blood lead to cognitive function: the VA normative aging study. Neurotoxicol Teratol 1998;20:19-27.

14 Prentice A. Maternal calcium requirements during pregnancy and lactation. Am f Clin Nutr 1994;598:477-83.

15 Tylavsky F, Curtis RC, Anderson JJB, et al. Changes in radial and vertebral bone mass due to pregnancy and lactation in humans. F Bone Miner Res 1989;4:S414.

16 tion in humans. F Bone Miner Res 1989;4:S414. Perspect 1990;89:101-5.

17 Bellinger D, Leviton A, Waternaux C, et al. Longitudinal analyses of prenatal lead exposure and early cognitive analyses of prenatal lead exposure and early
development. N Engl f Med 1987;316:1037-43.

18 Gonzalez-Cossio T, Peterson K, Luz-Helena S, et al. Decrease in birth weight in relation to maternal bone-lead burden. Pediatrics 1997;100:856-62.

19 Romieu I, Carreon T, Lopez L, et al. Environmental urban lead exposure in blood lead levels in children of Mexico City. Environ Health Perspect 1995;103:1036-40.

20 Somervaille LJ, Nilsson U, Chettle DR, et al. In vivo measurements of bone lead - a comparison of two x-ray flourescence techniques used at three different bone sites. Phys Med Biol 1989;34:1833-45.

21 Aro ACA, Todd AC, Amarasiriwardena C, et al. Improvements in the calibration of the ${ }^{109} \mathrm{Cd} \mathrm{k}$-x-ray flourescence systems for measuring bone lead in vivo. Phys Med Biol 1994;39:2263-71.

22 Skerfing S, Christoffersson J, Schutz A, et al. Biological monitoring, by in vivo xrf measurements of occupational exposure to lead cadmium and mercury. Biol Trace Elem Res 1987;13:241-51.

23 Hoppin JA, Aro ACA, Williams PL, et al. Validation of $\mathrm{K}-\mathrm{XRF}$ bone lead measurement in young adults. Environ Health Perspect 1995;103:78-83.

$24 \mathrm{Hu} \mathrm{H}$, Milder F, Burger DE. X-ray fluorescence measurement of lead in bone using x-ray fluorescence. Phys Med Biol 1985;30:929-43.

25 Hernandez-Avila M, Romieu I, Rios C, et al. Lead-glazed ceramics as major determinants of blood lead levels in Mexican women. Environ Health Perspect 1990;94:117-20.
26 Romieu I, Palazuelos E, Hernandez-Avila M, et al. Sources of lead exposure in Mexico City. Environ Health Perspect 1994;102:384-9.

27 Romieu I, Hernandez-Avila M, Rivera JA, et al. Dietary studies in countries experiencing a health transition. $A m \mathcal{F}$ Clin Nutr 1997;65:595-655.

28 Hernandez-Avila M, Romieu I, Parra S, et al. Validity and reproducibility of a food frequency questionnaire to assess dietary intake of women living in Mexico City. Salud Publica de Mexico 1998;39:133-40.

29 Kleinbaum DG, Kupper LL, Muller KE. Applied regression analysis and other multivariate methods. Chapel Hill, North Carolina: University of North Carolina, 1998.

30 Kim R, Aro A, Rotnitzky A, et al. K X-Ray fluorescence measurements of bone lead concentration: the analysis of low-level data. Phys Med Biol 1995;40:1475-85.

31 Hastie T, Tibshirani R. Generalized additive models. New York: Chapman and Hall, 1990.

32 Montoya-Cabrera MA, Maldonado-Torres L, LandazuriLaris $\mathrm{P}$, et al. Lead determinations in the blood of the umbilical cord of normal neonates. Archivos de Investigacion Medica (Mexico) 1981;12:457-62.

33 Claeys-Thoreau F, Thiessen L, Bruaux P, et al. Assessment and comparison of human exposure to lead between Belgium, Malta, Mexico, and Sweden. Int Arch Occup Environ Health 1987;59:31-41.

34 Counter SA, Buchanan LH, Laurell G, et al. Field screening of blood lead levels in remote Andean villages. Neurotoxicology 1998;19:871-7.

35 Staessen J. Low-level lead exposure, renal function and blood pressure. Verhandelingen-Koninklijke Academie voor Geneeskunde van Belgie. 1995;57:527-74.

36 Sole E, Ballabriga A, Dominquez C. Lead exposure in the general population of the metropolitan areas of Barcelona: blood levels and related factors. Sci Total Environ 1998;224: 19-27.

$37 \mathrm{Hu} \mathrm{H}$, Hashimoto D, Besser M. Levels of lead in blood and bone of women giving birth in a Boston Hospital. Arch Enviorn Health 1996;51:52-8.

38 Kosnett MJ, Becker CE, Osterloh JD, et al. Factors influencing bone lead concentration in a suburban community assessed by non-invasive $\mathrm{K} x$ ray fuorescence. fAMA 1994;271:197-203.

39 Roy MM, Gordon CL, Beaumont LF, et al. Further experience with bone lead content measurements in residents of Southern Ontario. Appl Radiat Isot 1997;48:391-6.

40 Rabinowitz M, Needleman H. Environmental, demographic and medical factors related to cord blood lead levels. Biol Trace Elem Res 1984;6:57-67.

$41 \mathrm{Hu} \mathrm{H}$, Rabinowitz M, Smith D. Bone lead as a biological marker in epidemiologic studies of chronic toxicity: conceptual paradigms. Environ Health Perspect 1998;106:18.

$42 \mathrm{Hu} \mathrm{H}$, Payton M, Korrick S, et al. Determinants of bone and blood lead levels among community-exposed middle-aged to elderly men. Am f Epidemiol 1996;144:749-59.

43 Hernandez-Avila M, Gonzalez-Cossio T, Palazuelos E, et al. Dietary and environmental determinants of blood and bone lead levels in lactating postpartum women living in Mexico City. Environ Health Perspect 1996;104:1076-82.

44 Fernandez GO, Fortoul TI, Palazuelos E. High blood lead levels in ceramic folk art workers in Michoacan, Mexico. Arch Environ Health 1997:52;51-5.

45 Romieu I, Lopez L, Carreon-Valencia T, et al. Determinants of blood lead levels among women in reproductive age and their children less than five years, living in Mexico City. Proceedings of Indoor Air 1993;93:439-43. 